\title{
THE INVESTIGATION OF RELATIONSHIP BETWEEN GAME SKILLS AND ATTENTION OF THE KINDERGARTEN STUDENTS ${ }^{1}$
}

\section{ANAOKULU ÖĞRENCILLERININ OYUN BECERILERİ İLE DIKKKATLERİ ARASINDAKI ILIŞKININ INCELENMESI}

\author{
Meryem ALTUN \\ Ömer Halisdemir University, School of Physical Education and Sports, Niğde / Turkey
}

ORCID ID: 0000-0003-1224-7927

Öz: Amaç: Bu araştırmada, anaokulu öğrencilerinin oyun becerileri ile dikkatleri arasındaki iliş̧inin incelenmesi amaçlanmıştır. Yöntem: Bu araştırmanın modeli, ilişkisel tarama modelidir. Araştırmaya, Kırşehir 80. Yıl Anaokulunda 20162017 eğitim öğretim döneminde öğrenim gören 6 yaş grubu 50 kı, 50 erkek olmak üzere toplam 100 öğrenci gönüllü olarak katılmıştır. Ölçme aracı olarak Oyun Becerileri Değerlendirme Ölçeği ve Frankfurter Dikkat Testi kullanılmıştır. Verilerin analizinde; SPSS 21 paket programı kullanılmıştır. Oyun becerileri puanları ve hesaplanan dikkat puanları veri setine girilip ölçek puanlarının normal dağılıma uygunluğunu test etmek için Kolmogrow-Smirnov testi kullanılmıştır. Cinsiyet değişkeni için Independent Samples t-testi, iki değiş̧en arasındaki ilişkinin incelenmesinde de Pearson Korelasyon testi kullanılmıştır. Demografik özelliklerde ise yüzde, frekans ve aritmetik ortalamalara bakılmıştır. Bulgular: Yapılan analizler sonucunda çocukların Oyun Becerileri ile Dikkat puan ortalamaları cinsiyet değişkenine göre anlamlı farklılık göstermektedir. Bu farklılık bayanların lehine görülmektedir. Oyun Becerileri puanları ile Dikkat puanları arasında pozitif yönde anlamlı bir ilişkinin olduğu bulunmuştur. Sonuç: Okul öncesi öğrencilerinin oyun becerileri ile dikkatleri arasında güçlü bir ilișki olduğu söylenebilir.

Anahtar Kelimeler: Anaokulu, Altı Yaş, Dikkat, Oyun Becerileri
Abstract: Aim: In this research, it is aimed to examine the relationship between play skills and attention of kindergarten students. Method: The model of this study is the relational search model. A total of 100 students ( 50 girls, 50 boys) participated in the research as a volunteer in the 6th year group of the Kırşehir 80th Year Nursery School during the 2016-2017 education period. The Game Ability Assessment Scale and the Frankfurter Attention Test were used as the measurement tools. In the analysis of the data; SPSS 21 package program was used. The Kolmogrow-Smirnov test was used to test the game performance scores and the calculated attention scores into the data set and to test the suitability of the normal distribution of scale scores. İt was used Independent Samples t-test for gender variables, Pearson Correlation test for the relationship between two variables. In the demographic characteristics, the percentages, frequencies and arithmetic averages are examined. Results: The results of the analyses show that, the mean scores of the children's game skills and Attention score are significantly different according to the gender variable. This difference is favored by ladies. As a result of the analysis made to determine whether there is a meaningful relationship between the game skills scores and the Attention scores, it was found that there is a meaningful relationship between them in the positive direction. Conclusion: According to this, it can be said that there is a strong relation between play skills and attention of pre-school students.

Key Words: Kindergarten, Six Age, Attention, Playing Skills

Doi: 10.17363/SSTB.2017.2.02

(1) Corresponding Author: Meryem ALTUN, Ömer Halisdemir University, School of Physical Education and Sports, Niğde / Turkey, mrymltn@hotmail.com, Received: 18.02.2017, Accepted: 23.06.2017, Type ofarticle (Research -Application) Conflict of Interest: None / "None of Ethics Committee" 


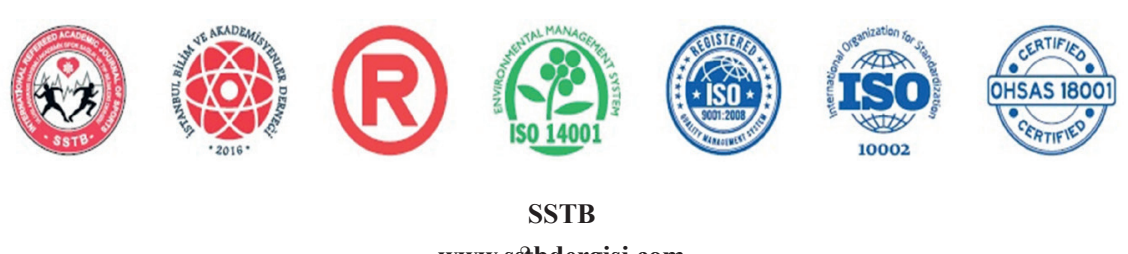

Www.sstbdergisi.com

International Refereed Academic Journal of Sports, Health and Medical Sciences

April - May - June Issue 23 Winter Season Year: 2017

JEL CODE: I2-I12-I20-I21-I29 ID:339 K:377

ISSN Print: 2146-8508 Online 2147-1711

(ISO 18001-OH-0090-13001706 / ISO 14001-EM-0090-13001706 / ISO 9001-QM-0090-13001706 / ISO 10002-CM-0090-13001706) (TRADEMARK)

(2015/04315- 2015-GE-18972)

\section{INTRODUCTION}

Attention, which has an important place in all aspects of human development and learning, is particularly necessary for the continuation of the learning process. Careful attention to detail can be kept in the individual's memory (Frommer, 1993: 7). It is seen that the concepts of collecting attention and attention are used synonymously in daily literature as well as scientific literature. The general tendency is to accept attention as an upper form of attention. Attention collecting is "the skill of consciously collecting the attention of the individual to a certain point" and in this process the individual's mental development, age, individual characteristics play an important role (Özdoğan, 2004: 24).

Aydın (1999: 49) Some negative variables that affect attention in school are as follows: Problems in the functioning of intelligence, perception and memory processes, the cognitive skills of the student and the psychomotor skills are not at the appropriate level, the internal (lack of nutrition and sleep, fatigue etc.) and external (heat, light, sound etc.) physical stimuli that the organism is in, excessive or insufficient motivation, inadequacy of feedback, worry about failure, extreme anxiety and tension, teacher-centered teaching strategies dominate education, empathic perception deprivation in classroom interaction, over-standardized success measures and an understanding of student performance evaluation, failure to meet the student's integrity and autonomy requirements in teaching, lack of a democratic, participatory and flexible teaching approach in education.

There are some techniques to get rid of this deprivation. At the beginning of these techniques is the game. As the Greeks have said about 2500 years ago: "Mens sano in corpore sano" - "A healthy mind in a healthy body." They have revealed this close relationship to the extent that they can observe what they are doing. In recent studies; that gymnastics exercises not only allow you to recover from excess pounds, correct your body lines, make you feel good, but at the same time you can think healthier and more importantly, delay aging in your brain (McCleary, 2009: 145).

In the Chinese people's community, participating in activities such as reading, writing, puzzle-solving, playing cards, playing card games, participating in group discussions and playing musical instruments, participated in these activities, $5 \%$ reduction in the risk of loss occurrences. The majority of the activities that increase the score in the positive direction are due to the habit of reading books and a Chinese Dominos called mahjong (McCleary, 2009: 161).

Young children are faced with new information every day and associating them with 


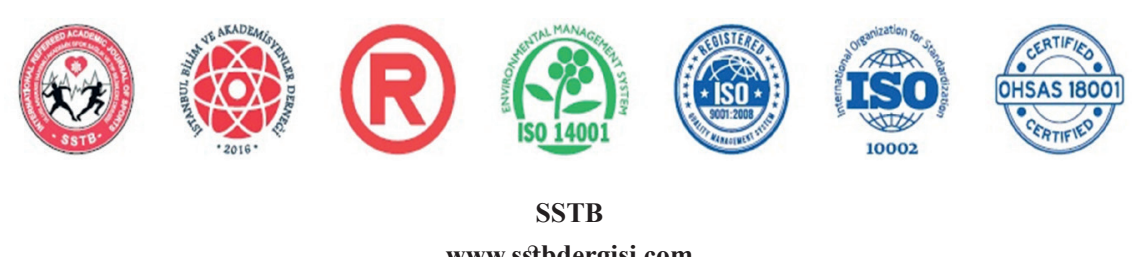

www.sstbdergisi.com

International Refereed Academic Journal of Sports, Health and Medical Sciences

April - May - June Issue 23 Winter Season Year: 2017

JEL CODE: I2-I12-I20-I21-I29 ID:339 K:377

ISSN Print: 2146-8508 Online 2147-1711

(ISO 18001-OH-0090-13001706 / ISO 14001-EM-0090-13001706 / ISO 9001-QM-0090-13001706 / ISO 10002-CM-0090-13001706)

(TRADEMARK)

(2015/04315- 2015-GE-18972)

concepts that they have already acquired or developing new concepts. It is necessary to support the multi-faceted development of the kindergarten (6 years old) children and to present them with a systematic and conscious education process which is the foundation of the life-long learning. Beginning to study is one of the most important steps that affect families, especially in their lives. Many important steps have been taken in this period, especially in the mental development of the child, and the education has been shifted to a more systematic, more concrete and necessary stage. If the child has not received preschool education; to move away from the family, to adapt to the new orientation, and to become academicly adept. Problems and level differences at the attention levels are evident in this period. Attention problems, which is an important issue to learn, emerge from the beginning of this period. These problems, which are known to be over a hundred years old, have begun to be discussed intensively in our country in recent years. There are educational games to support attention development that allow children to learn by playing. It is ensured that the behavior of the child playing with the selected games continues to be active in a certain period of time in line with the directions for the purpose of the game. The game on this counts; It can contribute to children's perception, attention and solution to problems.

\section{METHOD}

This study was done at the request of the schoolmaster. In this study, a relational search model was used to examine the relationship between play skills and attention of kindergarten students. Relational search model; Is a research model aimed at determining the presence and / or extent of exchange between two or more variables (Karasar, 2014: 77). A total of 100 students (50 girls and 50 boys) participated in the study in the Kırşehir 80th Year Nursery School during the 2016-2017 education period.

The demographic characteristics of the participants are given in table 1. 


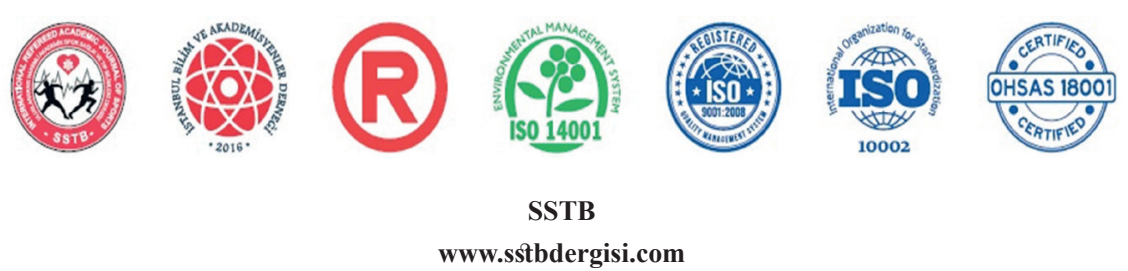

International Refereed Academic Journal of Sports, Health and Medical Sciences

April - May - June Issue 23 Winter Season Year: 2017

JEL CODE: I2-I12-I20-I21-I29 ID:339 K:377

ISSN Print: 2146-8508 Online 2147-1711

(ISO 18001-OH-0090-13001706 / ISO 14001-EM-0090-13001706 / ISO 9001-QM-0090-13001706 / ISO 10002-CM-0090-13001706) (TRADEMARK)

(2015/04315- 2015-GE-18972)

Table 1. Demographic Characteristics of Students

\begin{tabular}{|c|c|c|c|}
\hline & & Frequency $(\mathrm{N})$ & Percentage $\%$ \\
\hline \multirow{6}{*}{ Class } & Daisies & 21 & 21,0 \\
\hline & Smurfs & 19 & 19,0 \\
\hline & Ladybirds & 23 & 23,0 \\
\hline & Stars & 15 & 15,0 \\
\hline & Strawberries & 22 & 22,0 \\
\hline & Total & 100 & 100,0 \\
\hline \multirow{3}{*}{ Gender } & Famele & 50 & 50,0 \\
\hline & Male & 50 & 50,0 \\
\hline & Total & 98 & 100,0 \\
\hline Age & 6 & 100 & 100,0 \\
\hline
\end{tabular}

When the above frequency table is examined, it is seen that $50 \%$ of men and $50 \%$ of women are in terms of sex change.

\section{Data Collection Tools}

The data were collected using the Game Ability Assessment Scale and the Frankfurter Attention Test.

Game Skills Assessment Scale: The Skills Assessment Scale developed by Fazlığlu, Ilgaz and Papatağa (2013) is composed of 27 items using a 5-point Likert-type rating in order to determine what kind of playful skills the 6 year old children have during the game and to ensure that these skills are revealed by the parents. The Cronbach Alpha internal consistency coefficient of the scale was .93 .

Frankfurter Attention Test. (FTF-K) (Concentration-Attention Collecting Test for children 5-6 years old): Developed by Raatz and
Möhling (1971) and intended to measure children's attention-gathering skills, children are required to find and mark pears within 90 seconds of mixed apples and pears (Kuscu, 2010). In Turkey, this test has been applied to 30 children aged five to six years in terms of understanding and applying the tests in Clinical Psychology Practice course by the senior students of Ankara University Faculty of Educational Sciences. The reliability of the FTF-K test was determined by the test-retest method. The correlation between test 1 and test 2 is $r=0.79$. The scale was administered individually by each researcher to each child (Kaymak, 1995). The FTF-K Attention Collecting Test is administered by the researcher to each child individually or in small groups. In the test, the pears drawn by the child in 90 seconds form the raw score. At the same time this scale has been used in many studies in Turkey (Kaymak, 1995; Koçyiğit, Kayılı 


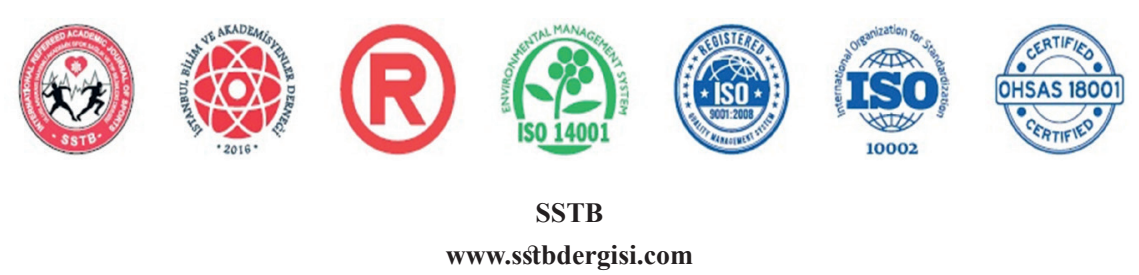

International Refereed Academic Journal of Sports, Health and Medical Sciences

April - May - June Issue 23 Winter Season Year: 2017

JEL CODE: I2-I12-I20-I21-I29 ID:339 K:377

ISSN Print: 2146-8508 Online 2147-1711

(ISO 18001-OH-0090-13001706 / ISO 14001-EM-0090-13001706 / ISO 9001-QM-0090-13001706 / ISO 10002-CM-0090-13001706)

(TRADEMARK)

(2015/04315- 2015-GE-18972)

and Erbay, 2010; Kayıl1 and Ar1, 2011; Erbay, 2013).

\section{Data Collection and Analysis}

The Game Skills Assessment Scale, which was used as a data collection tool in the study, was evaluated by the parents of the students. The Frankfurter Attention Test was administered to students.

In the analysis of the data; SPSS 21 package program is used. Game skills scores and calculated attention scores were entered into the

data set and the fitness of normal distribution of scale scores was tested by the KolmogrowSmirnov test. Büyüköztürk (2012) recommends the use of the "Kolmogorov-Smirnov" test if the number " $n$ " is over 50 and above. Independent Samples t-test for gender variables and Pearson Correlation were used for the relationship between two variables. In the demographic characteristics, the percentages, frequencies and arithmetic averages are examined.

\section{FINDINGS}

Table 2. Results of Tests of Children According to the Genders of Game Skills and Attention Levels

\begin{tabular}{lllllll}
\hline & Gender & N & X & S & F & P \\
\hline \multirow{2}{*}{ Game Skills } & Male & 50 & 2914,60 & 887,41 & \multirow{2}{*}{3,912} & $\mathbf{0 1 4}$ \\
\cline { 2 - 5 } & Famele & 50 & $34,29,66$ & 1150,34 & & \\
\cline { 2 - 5 } Attention & Total & 100 & & & \multirow{2}{*}{2,028} & $\mathbf{0 0 2}$ \\
\hline \multirow{2}{*}{ Male } & 50 & 26,36 & 6,34 & \\
\hline
\end{tabular}

According to Table 2, it was found that the difference between the results of the $t$ test for the independent samples made to determine whether the level of attention and gaming skills of the children differ significantly according to the gender variable. This difference seems to be in favor of the ladies $(p<.05)$. 


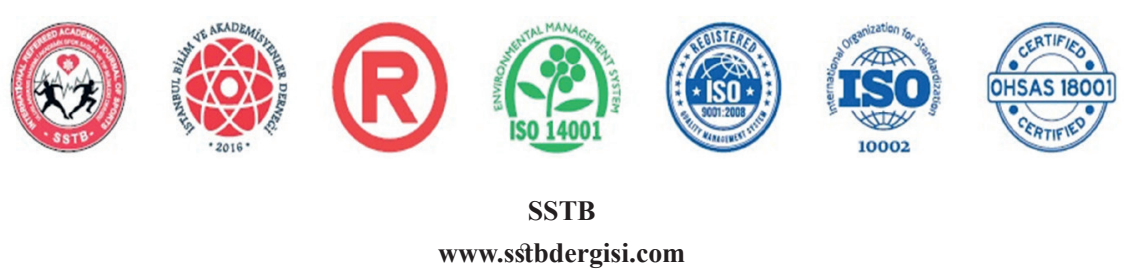

International Refereed Academic Journal of Sports, Health and Medical Sciences

April - May - June Issue 23 Winter Season Year: 2017

JEL CODE: I2-I12-I20-I21-I29 ID:339 K:377

ISSN Print: 2146-8508 Online 2147-1711

(ISO 18001-OH-0090-13001706 / ISO 14001-EM-0090-13001706 / ISO 9001-QM-0090-13001706 / ISO 10002-CM-0090-13001706) (TRADEMARK)

(2015/04315- 2015-GE-18972)

Table 3. Results of Relative Correlation Analysis between Children's Play Skills and Their Attention

\begin{tabular}{lll}
\hline Game Skills & & \\
\hline \multirow{3}{*}{ Attention } & $\mathbf{r}$ & $856^{* *}$ \\
& $\mathbf{p}$ &, 000 \\
& $\mathbf{n}$ & 100 \\
\hline
\end{tabular}

**. Correlation is significant at the 0.01 level (2-tailed).

According to 3 A Pearson correlation analysis was conducted to determine whether there is a significant relationship between Play Skills scores and Attention scores and found a significant positive correlation between them $(\mathrm{r}=.856, \mathrm{p}<.01)$. According to this, it can be said that there is a strong relation between play skills and attention of pre-school students.

\section{DISCUSSION}

In this study, the relationship between the attention of kindergarten students and play skills was investigated. According to the results of the research, the children 's game skills and attentiveness levels are significantly different according to gender. This difference seems to be in favor of the ladies.

As a result of numerous researches, children's genders affect their gaming behaviors, that the gender variable is even effective in selecting a playmate, it was determined that boys preferred physical games more and girls more preferred "play like" (Colwell and Lindsey, 2005; Connell and Prinz, 2002; Gerrits, Goudena and van Aken, 2005; Gleason, 2005; Lindsey and Mize, 2001a; Zachopoulou, Trevlas and Tsikriki, 2004). In addition, Uylaş, Yalçın, Panda Sari and Scarboro (2014) The gender variable determines the place of play, the size of the playgroup, the level of control, conflict resolution strategies and the justice standards applied to these solutions.

As a result of the analysis made to determine whether there is a meaningful relation between the game skill scores and the attention scores, it was found that there was a meaningful relation between them in the positive direction. According to this, it can be said that there is a strong relation between play skills and attention of pre-school students.

According to Mackey, Hill, Stone, Bunge (2011); and that the cognitive processes such as reasoning and processing speed can be changed and improved by game training are consistent with the results of the study. Benigno ve Farrar (2012), according to research 


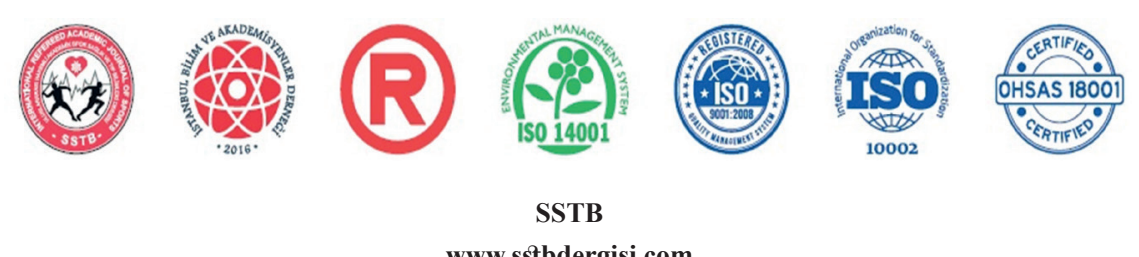

www.sstbdergisi.com

International Refereed Academic Journal of Sports, Health and Medical Sciences

April - May - June Issue 23 Winter Season Year: 2017

JEL CODE: I2-I12-I20-I21-I29 ID:339 K:377

ISSN Print: 2146-8508 Online 2147-1711

(ISO 18001-OH-0090-13001706 / ISO 14001-EM-0090-13001706 / ISO 9001-QM-0090-13001706 / ISO 10002-CM-0090-13001706)

(TRADEMARK)

(2015/04315- 2015-GE-18972)

findings on 32 siblings of the game the game played through siblings reached the conclusion that it affected the attention development.

According to the results of the research by Seçer and Özmen (2015) on the effects of attention-gathering activities on the thinking and attention-gathering skills of pretextual preschool children; it has been said that the activities of improving the attention collecting skill (play, etc.) applied to the children of the experimental group reduce the number of errors of the children and increase the attention collecting ability. aydin et. al. (2016) in the Zeka Investigation of the effects of brain teasers on attention spans of pre-school children of study; it was noted that there was a significant difference in the level of attention among the six-year-olds who were studying intelligence games and the six-year-old children who were educated according to the Ministry of Education Preschool Education Program in favor of the experimental group.

\section{CONCLUSION}

As a result of the analyzes made, the mean scores of the children's game skills and Attention score are significantly different according to the gender variable. This difference is favored by ladies. As a result of the analysis made to determine whether there is a meaningful relationship between the game skills scores and the Attention scores, it was found that there is a meaningful relationship between them in the positive direction. According to this, it can be said that there is a strong relation between play skills and attention of pre-school students.

\section{REFERENCES}

ALTUN, M., HAZAR, M., HAZAR, Z., (2016). Investigation of the effects of brain teasers on attention spans of preschool children. International Journal Of Environmental and Sclence Education, 11(15); 8112-8119

AYDIN, A. (1999). Gelişim ve Öğrenme Psikolojisi. Ankara: Anı

BENIGNO, J. P., FARRAR, M. J., (2012). Determinants of Joint Attention in Young Siblings' Play, Infant and Child Development Inf. Child. Dev. 21, Published online 31 August 2016 in Wiley Online Library

COL, Ş. (2012). Sosyal bilimler için veri analizi el kitabı: İstatistik, araştırma deseni, spss uygulamalarl ve yorum. (16. Bask1). Anakara: Pegem

COLWELL, M. J., LINDSEY, E. W., (2005). Preschool children's pretend and physical play and sex of play partner: Connections to peer competence. Sex Roles, 


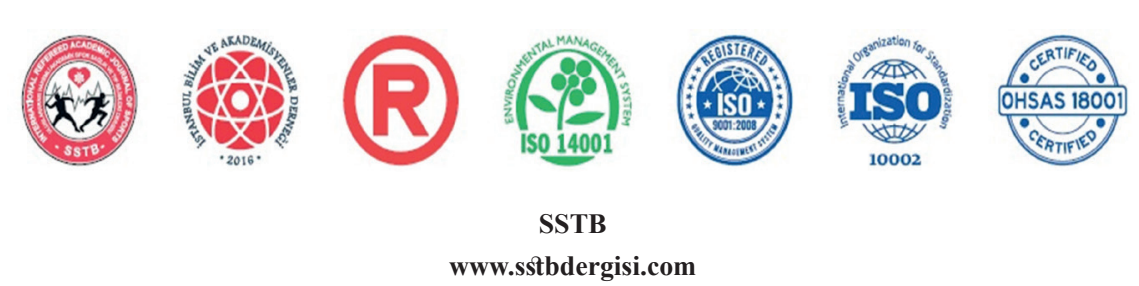

International Refereed Academic Journal of Sports, Health and Medical Sciences April - May - June Issue 23 Winter Season Year: 2017

JEL CODE: I2-I12-I20-I21-I29 ID:339 K:377

ISSN Print: 2146-8508 Online 2147-1711

(ISO 18001-OH-0090-13001706 / ISO 14001-EM-0090-13001706 / ISO 9001-QM-0090-13001706 / ISO 10002-CM-0090-13001706) (TRADEMARK)

(2015/04315- 2015-GE-18972)

52(7-8), 497-509. Doi: $\quad 10.1007$ / s11199-005-3716-8

CONNELL, C. M., PRINZ, R. J., (2002).

The impact of childcare and parent-child interactions on school readiness and social skills development for low-income African American children. Journal of School Psychology, 40(2), 177-193.Doi: 10.1016/S0022-4405(02)00090-0

ERBAY, F., (2013). Dikkat toplama ve okuma olgunluğu değişkenlerinin altı yaş çocuklarının işitsel muhakeme ve işlem becerilerini yordama gücü. Kuram ve Uygulamada Eğitim Bilimleri, 13(1), 422-429

FAZLIOĞLU, Y., ILGAZ, G., PAPATĞA, E., (2013). Oyun becerileri değerlendirme ölçeğinin geçerlik ve güvenirlik çalışması. Trakya Üniversitesi Sosyal Bilimler Dergisi, 15(1), 239-250

FROMMER, W., (1993). Yönlendirilmeden düşünerek yaşama. ( E. Duygulu, Çev.). İstanbul: Düşünen Adam

GERRITS, M. H., GOUDENA, P. P., VAN AKEN, M. A., (2005). Child-parent and child-peer interaction: Observational similarities and differences at age seven. Infant and Child Development, 14(3), 229-241. Doi: $10.1080 / 0300443011660108$
GLEASON, T. R., (2005). Mothers' and fathers' attitudes regarding pretend play in the context of imaginary companions and of child gender. Merrill-Palmer Quarterly, 51(4), 412-436. Doi: 10.1353/ mpq.2005.0022

KARASAR, N., (2014). Bilimsel Araştırma Yöntemi. (26. Basım). Ankara: Nobel

KAYILI, G., ARI, R., (2011). Examination of the effects of the Montessori Method on preschool children's readiness to primary education. Educational Sciences: Theory and Practice, 11(4), 2104-2109

KAYMAK, S., (1995). Yuvaya giden beş yaşındaki çocuklarla dikkat toplama çalışmaları. Yüksek Lisans Tezi. Ankara Üniversitesi Sosyal Bilimler Enstitüsü, Ankara

KOÇYİĞİT, S., KAYILI, G., ERBAY, F., (2010). Montessorri yönteminin beş-altı yaş çocuklarının dikkat becerilerine etkisinin incelenmesi. Çağdas Ĕ̆itim Dergisi, 35(371),16-21

KUSCU, Ö., ( 2010). Orff-Schulwerk yaklaşımı ile yapılan müzik etkinliklerinin okulöncesi dönemdeki çocuklarının dikkat becerilerine etkisi. Yüksek Lisans Tezi. Selçuk Üniversitesi Sosyal Bilimler Enstitüsü, Konya 


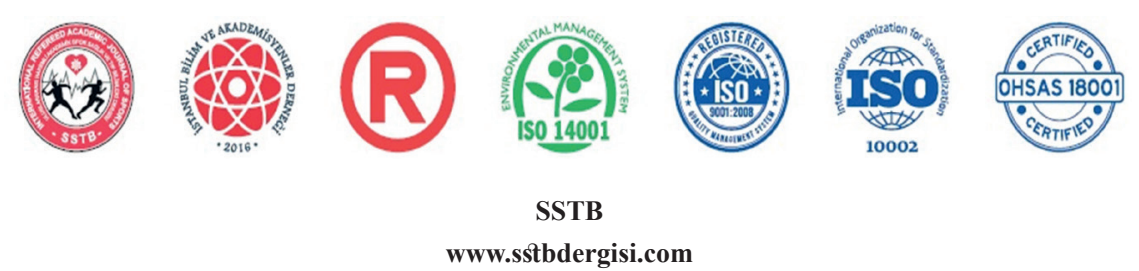

International Refereed Academic Journal of Sports, Health and Medical Sciences April - May - June Issue 23 Winter Season Year: 2017

JEL CODE: I2-I12-I20-I21-I29 ID:339 K:377

ISSN Print: 2146-8508 Online 2147-1711

(ISO 18001-OH-0090-13001706 / ISO 14001-EM-0090-13001706 / ISO 9001-QM-0090-13001706 / ISO 10002-CM-0090-13001706) (TRADEMARK)

(2015/04315- 2015-GE-18972)

LINDSEY, E. W., MIZE, J., (2001). Contextual differences in parent-child play: Implications for children's gender role development. Sex Roles, 44(3-4), 155-176. Doi: 10.1023/A:1010950919451

MACKEY, A. P., HILL, S. S., STONE, S. I. BUNGE, S. A., (2011). Differential effects of

reasoning and speed training in children. Developmental Science, 14(3), 582-590

http://onlinelibrary.wiley.com/doi/10.1111/ j.1467-7687.2010.01005.x,sayfasından erişilmiştir.

MCCLEARY, L., (2009). Beyin geliştirme programı. (A. Durmuş, Çev.). İstanbul: Crea

ÖZDOĞAN, B., (2004). Çocuk ve oyun: Çocuğa oyunla yardım. Ankara: Anı
SEÇER, Z., ÖZMEN, S. K., (2015). Dikkat toplamayı geliştirici etkinliklerin içtepisel okul öncesi ç o c u k la r ın düşünme ve dikkat toplama becerilerine etkisi. K. Ü. Kastamonu Eğitim Dergisi 23(4), 1803-1816

UYLAŞ, S., YALÇIN, H., PANDAMSARI, A., SCARBORO, A., (2014). "Can fatma come out and play?" gender and play in Istanbul. International Journal of Global Education, 3(1), 25-30

ZACHOPOULOU, E., TREVLAS, E., TSIKRIKI, G., (2004). Perceptions of gender differences in playful behaviour among kindergarten children. European Early Childhood Education Research Journal, 12(1), 43-53. Doi: 10.1080/1350293048520930 